CORRECTION

\title{
Correction: Using imaging photoplethysmography for heart rate estimation in non-human primates
}

Anton M. Unakafov, Sebastian Möller, Igor Kagan, Alexander Gail, Stefan Treue, Fred Wolf

The following information is missing from the Funding section: This study was supported by the German Research Foundation and the Open Access Publication Funds of the Göttingen University.

\section{Reference}

1. Unakafov AM, Möller S, Kagan I, Gail A, Treue S, Wolf $F$ (2018) Using imaging photoplethysmography for heart rate estimation in non-human primates. PLoS ONE 13(8): e0202581. https://doi.org/10.1371/ journal.pone.0202581 PMID: 30169537

\section{G openaccess}

Citation: Unakafov AM, Möller S, Kagan I, Gail A, Treue S, Wolf $F$ (2019) Correction: Using imaging photoplethysmography for heart rate estimation in non-human primates. PLOS ONE 14(1): e0211518. https://doi.org/10.1371/journal.pone.0211518

Published: January 25, 2019

Copyright: $\odot 2019$ Unakafov et al. This is an open access article distributed under the terms of the Creative Commons Attribution License, which permits unrestricted use, distribution, and reproduction in any medium, provided the original author and source are credited. 